\title{
Assimilation of the KWHL Model: A Review of Learning and Facilitation (LaF) of HOTS for Argumentative Essay Writing
}

\author{
Marzni Mohamed Mokhtar ${ }^{1}$, Marni Jamil'², Fadzilah Abd Rahman ${ }^{1}$, Roselan Baki ${ }^{1}$, \\ Rohizani Yaakub ${ }^{3}$, Fadzilah Amzah $^{3}$ \\ ${ }^{1}$ Department of Language and Humanities Education, Faculty of Educational Studies, Universiti Putra Malaysia, \\ Serdang Selangor, Malaysia \\ ${ }^{2}$ Academy of Language Studies, Universiti Teknologi MARA (UiTM) Cawangan Pulau Pinang, Malaysia \\ ${ }^{3}$ School of Educational Studies, Universiti Sains Malaysia, Pulau Pinang, Malaysia \\ Correspondence: Marzni Mohamed Mokhtar, Faculty of Educational Studies, Universiti Putra Malaysia, 43400 \\ Serdang, Selangor, Malaysia. Tel: 603-9769-8210. E-mail: marzni@upm.edu.my
}

Received: September 3, 2021 Accepted: September 28, 2021 Online Published: October 16, 2021

doi:10.5539/ass.v17n11p159

URL: https://doi.org/10.5539/ass.v17n11p159

\begin{abstract}
It is a necessity for teachers to develop higher-order thinking skills (HOTS) into learning and facilitation (hereafter known as $\mathrm{LaF}$ ) processes implemented in the classroom. Teachers should carefully balance the content of knowledge or knowledge they wish to convey and then integrate with other skills, especially HOTS. This research set out to examine the assimilation of HOTS into the LaF of argumentative essay writing as carried out by Malay language teachers in secondary schools. To obtain a holistic overview of the methods used by teachers in LaF, a qualitative case study approach was employed as the research design of this study. Two research participants were involved voluntarily in this study, and it was conducted at a boarding school in a district in Selangor, Malaysia. Data were collected through in-depth interviews and classroom observations with the two participants. The findings revealed that the assimilation of the KWHL model for the LaF of HOTS argumentative essay writing could be seen through (i) the pair-think-share activity; and (ii) the usage of self-assessment whiteboard.
\end{abstract}

Keywords: the KWHL model, higher order thinking skills, argumentative essay, case study

\section{Introduction}

\subsection{Assimilating the Higher Order Thinking Skills}

Efforts to assimilate Higher Order Thinking Skills (hereafter known as HOTS) into learning and facilitation (hereafter known as LaF) processes in schools that serve as an important part of the nation's educational agenda have made a significant impact on the Malay language educational system (Bahasa Melayu) (Yahya, 2003). As a result, the teaching of essay writing skills in the Malay language has come to be seen as an ideal opportunity to instill enhanced and sharpened thinking skills in students (Maharam, 2000; Roselan, 2001; Rajendran, 2008; Yahya, 2014; Abdul Rasid, Shamsudin, Azhar, \& Juanes, 2016). Writing skills require students to generate ideas, and have a sound knowledge of the accepted standards of essay writing. There is also the need to apply various thinking strategies to produce relevant ideas and keep a check on aspects of language to reinforce their essays.

Writing skills are considered the most complex of communication activities and are directly assessed in examinations. Therefore, a student must grasp a crisp and clear command of writing skills in line with the criteria set for essay writing for examinations, a fact which will inevitably boost the student's potential of obtaining an excellent level of achievement or even a distinction. The implication is that the overall achievement of a student in the Malay language subject exam could be enhanced, which would, in turn, affect the student's overall results in the Sijil Peperiksaan Malaysia (SPM) or the Malaysian Certificate of Education, since passing the Malay language paper in the said examination is compulsory for all students. Consequently, the identification of all the key aspects of teaching essay writing skills could produce Malay language education practitioners who are more focused on guiding and educating students.

The assimilation of HOTS in the LaF process by teachers could help students master competent language skills and self-learning in a more profound, consistent, productive and effective way (Yahya, 2014). Siti Khairiah 
(2012) also stated that when carrying out LaF, a Malay language teacher should exhibit expertise, and be thoroughly engaged to achieve the following (i) the obtaining of pedagogical knowledge; (ii) the obtaining of content knowledge; (iii) the providing of a conducive learning environment; (iv) the boosting of students' knowledge by merging language proficiency with activities which possess elements of HOTS such as exploring, information search; reporting, and product creation; and (v) the cultivating of a love for the Malay language. If all the above-mentioned roles are effectively practised, the teachers' rightful claims as the proponents of thinking pursuits among students could be fulfilled to actualise the agenda of national education to assimilate HOTS into the $\mathrm{LaF}$ process. The assimilation of HOTS into $\mathrm{LaF}$ is crucial to cultivate a lifelong learning attitude among students. This fact is proven through a statement made in Malaysian Education Blueprint (MEB) (2013-2025).

Each student needs to develop proficient inquiry and learn ways to continuously receive lifelong knowledge in order to possess command of various knowledge streams, and create new knowledge. Higher order thinking skills and the capacity to effectuate innovation is particularly critical in the rapid technological growth of technology. Each student is required to master a diverse range of cognitive skills such as creative and innovative thinking (potential to innovate, generate new probabilities and create ideas and new knowledge); critical thinking and reasoning (ability to analyse information, troubleshoot and approach issues at hand critically, logically inductively and deductively as means of finding solutions and eventually arriving at sound decisions); and learning abilities (ability to drive self-learning, as well as the potential to appreciate lifelong learning values).

(Ministry of Education Malaysia, 2013: Section 2-5)

The production of quality writing outputs is also strongly influenced by the LaF implemented by teachers. This is because the teacher's knowledge of the content of the writing, the construction of writing and the use of effective teaching strategies greatly help students develop cognitive ability in building links and continuity of ideas in the process of writing discourse (Marohaini, 2004). In addition, the use of effective teaching and learning strategies, as well as methods to implement HOTS in LaF, can develop students' minds (Wan Mat \& Norkhairiah, 2011; Sharifah Nor, Nor Adibah, Mohd Mahzan \& Aliza, 2012). In this study, two main issues that are highlighted related to teachers' pedagogical knowledge, namely the application of HOTS in LaF and teachers' content knowledge, which is the process of writing argumentative essays. For issues involving teachers' pedagogical knowledge related to the application of HOTS in LaF, various researches related to the application of HOTS in disciplines at the school level have been conducted (Md. Yusof, 2006; Suhaimi, Baharuddin, Hasnah, Norasykin \& Zaleha, 2014; Yahya, 2014; Muhamad Sidek, 2016). Most researchers have the same core of recommendation that HOTS should be improved through the use of effective teaching methods, approaches, techniques or strategies. The variety of these approaches, techniques or strategies act as triggers that can stimulate and generate students 'cognitive abilities during PdPc implementation (Shamsuddin, Ruzlan, \& Siti Noor, 2016).

To ensure that the above-discussed purpose is ably accomplished, Malay language teachers are expected to consistently integrate creative and innovative elements into their delivery of learning content. This is necessary seeing that the role of a Malay language teacher is not defined by teaching the language as it is delineated in the syllabus alone; instead, the teacher is also required to act as one who propels and opens up young minds by giving equal consideration to the underlying elements of the syllabus (Yahya, 2014). Additionally, Malay language teachers are also required to play a crucial role in empowering the minds of students to ensure that HOTS is effectively mastered to enable enhancement of their language proficiency since through the assimilation of HOTS, students will be able to control, dictate the direction of, and measure the progress of their lessons (Yahya, 2014).

It has become necessary for teachers to strive and produce individuals who are knowledgeable, skilled, and possess spiritual resilience and distinctive personality (Zarina, 2016). To ensure the successful realisation of HOTS's vision and goals, teachers must possess, and exhibit expertise in knowledge and intellectual strength of the highest order; strong professional skills that are further empowered by competency in new skills and technologies; sound appreciation of teaching values and ethics; as well as individual strengths and admirable personalities that are in tandem with the nation's aspirations.

\subsection{The Argumentative Essay}

The argumentative writing pedagogy entails students to think using HOTS, hence teachers' effective mastery and delivery of knowledge is essential as each phase demands them to present students with the task of designing, translating ideas, revising, refining, and perfecting the work repeatedly through the engagement of very complex cognitive activities in producing high-quality writing (Rajendran, 2000, 2001a, 2001b, 2001c, 2002 \& 2008). In 
addition, teachers with high mastery of argumentative writing skills can overcome constraints in T\&L based on HOTS particularly in the essay writing process, when it comes to students' struggle in finishing the argumentative essay writing assignments (Wolfe, Britt, \& Butler, 2009). Besides that, it was discovered that students were confused about the selection of assignment titles (Wei Zhu, 2001) and they were also limited by the argumentative essay page requirement (Wei Zhu, 2001).

Students were found to face challenges in terms of structuring and organising ideas (Hyland, 1990; Jalil \& Sukor, 2008; Wei Zhu, 2001), and applying imprecise discourse markers to begin new paragraphs (Wei Zhu, 2001). Moreover, the challenges also include their inability to connect evidence with arguments and assumptions in an argumentative essay writing (Cho \& Jonassen, 2002; Brudvik, Hong, \& Chee, 2006; Moore \& MacArthur, 2011), draw conclusions on the issues being debated (Wei Zhu, 2001) or diversify correct diction and use grammatical sentences in argumentative writing to support the argument (Wei Zhu, 2001; Abdul Jalil et al., 2008; Yusfaiza \& Mohd Isha, 2012).There was also no adherence to the format and guidelines with irregular essay structure by the students, which eventually required the guidance of teachers to fulfil the question requirements (A. Rahman, Jamaludin \& Zamri (2015). Sahlan, Shalinawati dan Saemah (2013) found that in regards to the essay title, there were students who only wrote one or two statements without elaborations on current issues, and wrote an introductory paragraph with irrelevant content (Sahlan, Shalinawati, \& Saemah, 2013).

\subsection{The KWHL Model}

The Ministry of Education (MOE) is cognizant of the fact that in Malaysia's educational system, thinking skills are used to aid students in their $\mathrm{LaF}$ activities which involve conceptualising, decision making and problem-solving. Sensing the need, the Curriculum Development Division (CDD) of MOE devised a model in 2002 which was used to teach thinking skills in schools. The thinking skills model that was developed by the CDD was an adaptation of four existing thinking models (Rajendran, 2001; Siti Zabidah, 2006) which comprise the KWHL model (Barell, 2002/2003), the Boston model (Swartz \& Parks, 1993), the CoRT model (de Bono, 1997) and the Programmed Instruction in the Learning Thinking Skills or PILTS model (John Arul Philips \& Fatimah, 1992). In this paper, the researchers will only be discussing the assimilation of the KWHL model.

The KWHL model was developed by John Barell (2002/2003) to promote the thinking skills of students who are engaged in information-seeking activities without attempting to classify the said thinking skills into specific categories. The model includes graphic chart management known as Advance Organizer which functions as a link between students' existing knowledge and new knowledge that will be taught (Maria \& Nurulhuda, 2013). The KWHL model comprises Knowledge ( $\mathrm{K}$ - list of what students Know) that refers to students' existing knowledge and the use of critical thinking to identify what is already known; What (W - List of what students Want to know or are Wondering) that is perceived to be acquired knowledge that requires critical and creative thinking; How (H- List of How to go about getting what students are supposed to achieve) which encompasses methods of securing relevant knowledge and involves creative thinking; and Learnt (L- List of what students Learnt) which is learned knowledge and which involves critical and creative thinking. Figure 2.10 demonstrates how the KWHL chart is created for the use of students during LaF in the classroom:
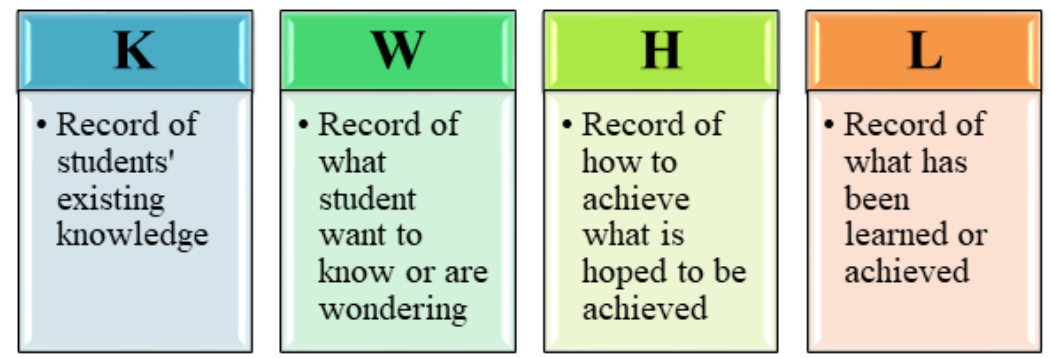

Figure 1. The KWHL Model Flow Chart (Adaptation from Maria \& Nurulhuda, 2013)

\subsection{Research Purpose and Research Questions}

This research set out to examine the assimilation of HOTS into the LaF of argumentative essay writing as carried out by Malay language teachers in secondary schools. The research question is as follows:

i. How is the assimilation of HOTS into the LaF of argumentative essay writing implemented by the Malay Language teachers in secondary schools? 


\section{Research Method}

A qualitative case study research was carried out in this study to enable researchers to elaborate on the experience, behaviour, emotion, sentiment, and interaction between research participants on the issues discussed, as recommended by Siti Hawa \& Santhiram (2001); Noriah, Siti Fatimah, Mohd Izham \& Siti Rahayah (2010). Gerring (2007) concludes that among the specific features of qualitative case studies are (i) studies involving a small number of samples; (ii) a thorough and in-depth study to describe a case or phenomenon studied; (iii) the data collected are obtained in a real or natural context; (iv) requires a triangulation process; (v) uses evidence from specific processes (participatory observations, field studies, clinical trials, historical studies, and others.); (vi) the dissemination of a topic that is difficult to distinguish between the case studied and the actual context of the study; (vii) studies involving a single observation and (viii) studies involving a single phenomenon, example or evidence.

In Malay language education, two main steps to be implemented in the process of Malay language teaching and learning naturalisation process ( $\mathrm{PdP})$ include (i) the practice on the mastery of accurate sentence structure in accordance with the context of language use; and (ii) the involvement of students in language use activities (communication activities) planned by the teacher to enable students to use the selected structure in the context of language use (Marzni \& Marni, 2021). Qualitative research design is of choice among researchers in the field of Malay language because of its qualitative case study ability to make detailed descriptions of the PdP naturalisation process. In light of this, the researchers attempted to understand the adjustment through a detailed inquiry into the Malay Language teachers' experiences, rather than proving or refuting any predetermined hypotheses. Hence, a qualitative approach is deemed to be more appropriate for this study (Ahrari et al., 2019), as the approach offers direct access to the subjective experiences of the Malay Language teachers' adaptation.

\subsection{Participant (Subject) Characteristics}

This study involved the participation of two Form Four Malay language teachers who acted as data providers. The teachers, Mr Fahmi (not his real name) and Mr Rahimi (not his real name) volunteered to participate in this study. The researcher used the purposive sampling method because the research participants were considered to be experts who possessed significant information in relation to the issues studied (Mason, 2002; Maxwell, 2008; Merriam, 1988 \& 2009). The criteria for participants' inclusion in the study include: (a) participants' voluntary participation without coercion; (b) participants hold a degree in the Malay Language Education (c) participants are teachers who teach Form Four Malay Language subjects; (d) participants possess more than five years of teaching experience; and (e) participants' willingness to share personal experiences with the researcher.

Table 1. Participants Profile

\begin{tabular}{|c|c|c|}
\hline \multicolumn{2}{|l|}{ Participants Profile } & \multirow{2}{*}{$\begin{array}{l}\text { Duration of Observing } \\
\text { Process and In depth } \\
\text { Interviews }\end{array}$} \\
\hline Mr Fahmi (not his real name) & Mr Rahimi (not his real name) & \\
\hline 36 years old & 31 years old & \multirow{6}{*}{$\begin{array}{l}\text { LaF } \\
\text { (Observation/ Recording) } \\
80 \text { minutes x } 7 \text { sessions = } \\
560 \text { minutes }\end{array}$} \\
\hline Man & Man & \\
\hline Malay & Malay & \\
\hline Banting, Selangor, Malaysia & Taiping, Perak, Malaysia & \\
\hline Degree of Malay Language Education & Bachelor of Education: Teaching & \\
\hline UPSI (1999-2003) & Malay as a First Language & \\
\hline 13 years of teaching experience & UPM (2005-2009) & \multirow{5}{*}{$\begin{array}{l}\text { In-depth Interviews } \\
60 \text { minutes } \times 7 \text { sessions }= \\
420 \text { minutes }\end{array}$} \\
\hline Boarding School 1(2003-2014) & 8 years of teaching experience & \\
\hline Boarding School 2 (2014-2021) & Boarding School 1 (2009-2014) & \\
\hline Excellence Service Award (2013) & Boarding School 2 (2014-2021) & \\
\hline $\begin{array}{l}\text { The } 11^{\text {th }} \text { Malaysian Best Boarding School Subject } \\
\text { Teacher Award (2013) }\end{array}$ & First Batch of i-Think Instructor & \\
\hline
\end{tabular}

\subsection{Data Collection Process and Data Analysis}

The data collection process employed two key techniques; in-depth interviewing, and classroom observation. All data were analysed using the thematic analysis technique to build on criteria and relevant themes to answer the research question. Data collected were through the in-depth interviewing technique, 14 times (seven times for each participant); classroom observation for LaF, 13 times (six times for each participant, and concurrent observation for the last session); and document analysis of argumentative essays, textbooks, workbooks, 
circulars, teachers' daily teaching plans (TDTP), debate texts and presentation or group work materials.

\section{Results}

The assimilation of the KWHL model for the LaF of HOTS argumentative essay writing could be seen through: -

\subsection{The Pair-think-share Activity}

Assimilation of the KWHL model in this study could be seen through the efforts of Mr Fahmi and Mr Rahimi, who carried out the pair-think-share activity. The pair-think-share activity involved idea-sharing within a stipulated period between two students on a topic chosen by the teacher, the results of which are required to be shared with the rest of the class. A description of the said activity can be found in the passage below:

Mr Fahmi: $\quad$ Pair-think-share is about share, share, share, share which means that we are required to share our materials with the classmate beside us, we tell stories, about what he knows; what he wishes to know and what the friend beside him, who heard stories from the friend beside him, learnt ooo so when we talked about neighbourliness earlier, we meant that knowing someone isn't enough and that we have to visit their homes, that's how it is (IV6/line 236-242)

Mr Rahimi: $\quad$ So it's like errr pair and think, there are two students and then they errr share ideas with each other, the friend sees, he then checks and ticks ok (IV12/line 59-61)

Mr Fahmi also considers pair-think-share activities as one of the features of student-centred learning. This is because students will discuss and share ideas with their peers. The following excerpts illustrate this feature:

Mr Fahmi: $\quad$ The main feature is based on student-centeredness, so it is written that the students discuss, share what they know with their peers, what they want to know, what they learn, and all these show student-centeredness (IV6 /ines 142-146).

In addition, Mr Fahmi and Mr Rahimi are also confident that the pair-think-share activity can be used well to apply HOTS in LaF of argumentative essay writing because students can do this activity well. The following are the views of both study participants:

Mr Fahmi: $\quad$ The student shares as he gets ideas through the sharing of ideas with the peer next to him (IV6/line 244).

Mr Rahimi: $\quad$ Before conducting the activity, I was studying the LaF approach with little understanding. However, for today, I tried to see if it is suitable for students when they use pair-think-share. I can see that it can be used based on today's lesson. (IV12/lines 252-256).

Furthermore, Mr Fahmi and Mr Rahimi also expressed their views on the selection of student pairs to ensure the effectiveness of the implementation of pair-think-share activities. According to Mr Fahmi, students are given the freedom to choose their partner to share ideas or tell stories about the topics discussed. According to Mr Fahmi, he stresses the importance of comfort and compatibility of students to share ideas. The following are his views:

As for me, I don't emphasize who the pair is. Rather, it is the willingness of the student whether to share or not during the sharing process (IV116/ line 255-257).

Mr Fahmi:

For me, it is about compatibility with the partner (IV16/ lines 259-260).

Yes. The comfort of the students is more emphasized compared to the others (IVI6/ lines 275-276).

\subsection{Usage of Self-Assessment Whiteboard}

Mr Fahmi, on his initiative, prepared a self-assessment whiteboard to be given to all students during the assimilation of HOTS in the LaF of argumentative essay writing. According to Mr Fahmi, the use of a self-assessment whiteboard is an innovative example of the type of individual whiteboard used (IV6/line 84-85). The self-assessment whiteboard initiative was divided into three key sections that comprise Know, What to know and Learned. The following passage depicts the sections that are found on the self-assessment whiteboard:

The meaning is as it is in English, Know, Know, What do they know and then Want, but I do

Mr Fahmi: not want to use want because want may be seen as what they want (IV6/ line 127-130).

So I write there, adapted to wishes to know, I do wish to change want, so I made it as wishes to know, WTK, K, and Learned, so it becomes easier for learning the writing process (IV6/line 132-134).

The justification provided by Mr Fahmi for using the self-assessment whiteboard as an instrument is that it can be used to replace computers and mobile phones as a teaching medium and because he found it to be a tool that 
could sustain the attention of students into the LaF activities he had carried out. This can be observed in the following passage:

Mr Fahmi: $\quad$ Replace computers, perhaps with ... with what errr group whiteboard, this is what we could do as suggested by these friends to replace computers. It's more like replacing tools, for schools that do not have computers, one can pick a whiteboard to show or teach the 21st Century Learning method (IV6/line 164-168).

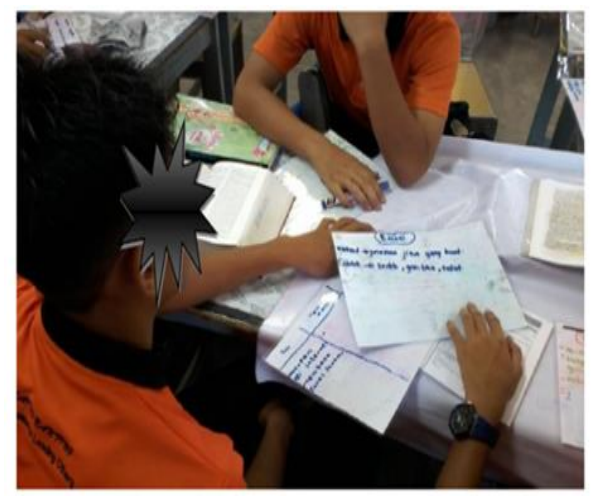

Figure 2. Example the Usage of Self-Assessment Whiteboard ( $3^{\text {rd }}$ Observation)

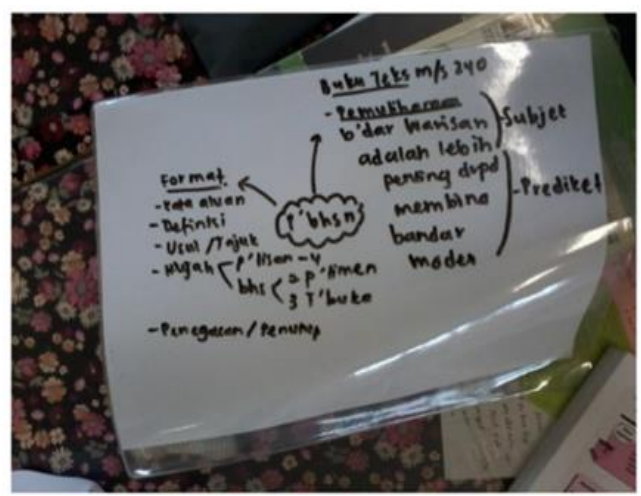

Figure 3. Example the Usage of Self-Assessment Whiteboard $\left(10^{\text {th }}\right.$ Observation

\section{Discussion}

The CDD Thinking Skills model (2002) focuses on four main domains which are critical thinking skills (relevance of ideas), creative thinking skills (absorption and generation of new ideas), thinking strategies (thinking process) and reasoning skills (logical and rational consideration) (Zaini, Juriah, \& Zarin, 2013; Wan Shahrazad \& Rozainee, 2006). Upon scrutiny of the study's findings that were examined using the assimilation of the KWHL model, it can be deduced that on the whole, the assimilation of the model can impact knowledge users (students) and educational practitioners (teachers) into gaining proficiency in argumentative essay writing. This is because all three domains of the CDD Thinking Skills Model are implemented using (i) teachers' understanding of the $\mathrm{LaF}$ of argumentative essay writing skills; (ii) teaching methods for the $\mathrm{LaF}$ of argumentative essay writing; and (iii) thinking tools that are used for the assimilation of HOTS for the LaF of argumentative essay writing. The assimilation of the KWHL model, which is carried out through LaF activities of argumentative essay writing such as pair-think-share and the use of self-assessment whiteboard, is extremely crucial for students to ensure that they can gain mastery of the structures of essay writing.

The assimilation of the KWHL model into the LaF of HOTS argumentative essay writing carried out in this study is believed to have been made possible by the awareness possessed by the two research participants of the current boom in information and communication technology (ICT) that strongly influences LaF conducted in classrooms. The ICT boom has provided students with wide access to publicly available information which effectively prepares them for the future. The findings of this research are in tandem with findings by Abu Bakar (2013) and Maimunah \& Hashimah (2017) which state that teachers must include elements of HOTS that could encourage students to think at a higher level to cohere with the knowledge that they receive. As for students' gaining of mastery of essay writing structures and developing of abilities to produce HOTS-accordant essays, it was noted that they must first be trained to approach writing with mature thinking strategies to effectuate power of imagination of the highest level, and optimise their cognitive abilities to generate sound ideas (Sulaiman \& Ahmad Khair, 2007; Suria \& Juriah, 2010; Zarina, 2016).

For the finding that was about the future of the students, it was discovered that the awareness possessed by both research participants of the important role played by HOTS in designing the future of the students, is similar to the recommendation made by Nur Hidayah (2015). Both the research participants applied HOTS into the LaF of argumentative essay writing as a preliminary step towards preparing students for the assimilation of HOTS towards fulfilling their academic and everyday demands. The assimilation of the KWHL model into the LaF of the HOTS argumentative essay writing is also implemented by teachers across curriculums, knowledge disciplines and local and global educational system changes. The research finding that showed that the assimilation of HOTS into LaF is crucial for teachers in their efforts to cultivate HOTS, is similar to the view of 
Kamsiah (2002), Aminah (2003), Maimunah (2004) and Abdul Halim (2016). This notion can be seen in the assimilation of HOTS into LaF that was carried out by both the research participants, which suggests that they were consciously cultivating HOTS to respond to MOH's call, as clearly delineated in the MEB (2013-2025). Teachers must make conscious efforts to cultivate HOTS-centred thinking into LaF that they carry out to ensure the smooth delivery of multidisciplinary knowledge. Through the assimilation of HOTS, students are continuously encouraged to think fast, and approach issues or topics discussed during the LaF of writing skills from various perspectives. HOTS is also a thinking process that crosses the boundary of curriculums and knowledge disciplines. This particular research finding is in tandem with the concept introduced by MOF (2013) and Abdul Halim (2016). This also further suggests that both the research participants were aware that the assimilation of HOTS into LaF has dominated all branches of knowledge. The demand for change in the global educational system has also affected a ripple effect on the local educational system. Thus, in the context of the argumentative essay writing process, HOTS is a very relevant concept that must be positioned as the essence of $\mathrm{LaF}$ in classrooms.

Teachers are further encouraged to begin executing foundational stabilisation processes in essay writing for students from the lower secondary levels to ensure that the latter develop a thorough understanding of outline creation and content development for essays from the early stages of their secondary school education (Maharam, 2000; Musa, 2002; Roselan, 2003a \& 2003b). The stabilisation process includes discussions in classrooms; diversity in teaching techniques such as exposure to stylistic essay writing techniques that could enhance the readability factor; use of the ICT medium to sustain the interest of the students in LaF; and use of varied teaching aids (Nur Hidayah 2015). Additionally, the sharing of expertise by teachers who have received Excellence awards and School Improvement Specialist Coaches (SISC+) with Malay language teachers have also opened up possibilities of effective and systematically planned LaF processes to ensure that students master essay writing techniques correctly (Rozita \& Abdul Rasid, 2012).

Teachers must be shrewd in identifying students with poor proficiency in writing skills (Mahzan, 2007 \& 2008; Abdul Rasid, 2011). Identification of students' potentials to achieve excellence will guide teachers to effectively execute their coaching processes. Subsequent coaching sessions could include the different types of formatted and unformatted essays; scrutiny of students' essays against marking schemes, and from a grammatical point of view; emphasis on the correction of students' writing errors, which must be carried out as an effort to recognise strengths and weaknesses of students in essay writing; and attempts to assist students to gain general proficiency in various fields of writing (Che Zanariah \& Fadzilah, 2011). If Malay language teachers are willing to make conscious efforts to effectively shoulder such responsibilities, efforts to conduct LaF of Malay language based on HOTS will most certainly be continuous The CDD Thinking Skills model (2002) focuses on four main domains which are critical thinking skills (relevance of ideas), creative thinking skills (absorption and generation of new ideas), thinking strategies (thinking process) and reasoning skills (logical and rational consideration) (Zaini, Juriah, \& Zarin, 2013; Wan Shahrazad \& Rozainee, 2006).

\section{Conclusion}

The assimilation of HOTS into the LaF of argumentative essay writing is a challenge that needs to be handled effectively and synergised with pedagogical knowledge and teachers' content knowledge. It has also become increasingly important for teachers to act smartly to synergise the best methodologies, approaches, strategies and teaching techniques to match students' receptiveness, and current demands made in the field of education. Such awareness among teachers is crucial to ensure that knowledge culture in classrooms is given due importance without setting aside the key aspects that must be learnt and mastered by students. The assimilation of HOTS into the LaF of argumentative essay writing does bring in a positive impact for people from all walks of life including students, teachers, administrators, the ministry and the general public. On the whole, Malay teachers can and should take class discourses to a higher level by assimilating HOTS into the LaF of all language components (Noor Rohana, 2007a). Teachers should also provide learning situations that are more conducive and challenging to ensure that the learning of the Malay language is not perceived as boring, and students can master language skills at a competent level (Yahya, 2014). Malay language education is believed to play a huge impact in its role as the proponent of the society's culture of thinking seeing that the Malay language is the nation's official language.

\section{Acknowledgments}

Marzni Mohamed Mokhtar, Marni Jamil, Fadzilah Abd Rahman, Roselan Baki, Rohizani Yaakub and Fadzilah Amzah are grateful to share gratitude with the participating reviewers, participants in this research for their behind-the-scenes work in bringing this all to fruition. 


\section{References}

Abdul Halim, A. (2016). Higher-order thinking skills: The aspects of the curriculum, pedagogy, and assessment. In S. Johari, I. Nor Hasniza, H. A. Abdul, \& B. Yusof (Eds.), Kemahiran berfikir aras tinggi dalam pengajaran dan pembelajaran (pp. 121-149). Johor, Skudai: Fakulti Pendidikan Universiti Teknologi Malaysia.

Abdul Jalil, O., Mahzan, A., \& Rahmad, S. A. (2008). The use of grammatical and lexical cohesion in argumentative and expository writing mods. Masalah Pendidikan, 31(1), 135-146.

Abdul Rasid, J., Shamsudin, O., Azhar, M. S., \& Juanes, M. (2016). Availability of teachers in the implementation of teaching thinking skills in essay writing non-Malay students. PENDETA - Jurnal Bahasa, Pendidikan \& Sastera Melayu, 7, 1-8.

Abu Bakar, N. (2013). Curriculum towards the production of critical, creative, and innovative thinking skills. Jurnal Kurikulum dan Pengajaran Asia Pasifik 1(1), 10-18.

Ahrari, S., Krauss, S. E., Suandi, T., Abdullah, H., Sahimi, A. H. A., Olutokunbo, A. S., \& Dahalan, D. (2019). A stranger in a strange land: Experiences of adjustment among international postgraduate students in Malaysia. Issues in Educational Research, 29(3), 611-632.

Aminah, A. (2003). Pembelajaran berasaskan minda dan implikasinya kepada pendidikan. Siri Syarahan Umum Pelantikan Profesor Pelantikan 2003/Bil.2. Tanjung Malim: Penerbit Universiti Sains Malaysia.

Armstrong, W. S., \& Fogelin, R. (2010). Understanding arguments an introduction to informal logic (8th ed.). Virginia: Wadsworth Cengage Learning.

Arshad, M. (2007). Memperkasa proses pengajaran dan pembelajaran bahasa Malaysia di sekolah. Masalah Pendidikan, Jilid, 30(1), 79-87.

Arshad, M. (2008). Pendidikan literasi bahasa melayu strategi perancangan dan pelaksanaan. Kuala Lumpur: Utusan Publications \& Distributors Sdn. Bhd.

Barell, J. (2003). Developing more curious minds. Virginia: Association for Supervision and Curriculum Development Alexandria.

Brudvik, O. C., Hong, K. H., Chee, Y. S., \& Guo, L. (2006). Assessing the impact of a structured argumentation board on the quality of students' argumentative writing skills. In Proceedings of the 14th International Conference on Computers in Education (pp. 141-148). Amsterdam, IOS Press.

Buchman, A. D., \& Jitendra, A. K. (2006). Enhancing argumentative essay writing of Fourth-grade students with learning disabilities. Learning Disability Quarterly, 29, 39-54. https://doi.org/10.2307/30035531

Centre of Curriculum Development. (2002). Kemahiran berfikir dalam pengajaran dan pembelajaran. Putrajaya: Ministry of Education, Malaysia.

Che Zanariah, C. H., \& Fadzilah, A. R. (2011). Implementation of teaching and learning of writing skills in primary schools. Jurnal Pendidikan Bahasa Melayu, 1(1), May, 67-87.

Cho, K. L., \& Jonassen, D. H. (2002). The effects of argumentation scaffolds on argumentation and problem solving. ETR \& D, 50(3), 5-22. https://doi.org/10.1007/BF02505022

Coker, D. L., Jr., \& Erwin, E. (2011). Teaching academic argument in an urban middle school: A case study of two approaches. Urban Education, 46(2), 120-140. https://doi.org/10.1177/0042085910377426

Dawam, Md. Y. (2006). Mengajar kemahiran berfikir dalam mata pelajaran bahasa Melayu di sekolah rendah: satu kajian di sebuah sekolah di Mersing, Johor (Degree Dissertation). Fakulti Bahasa: Universiti Pendidikan Sultan Idris.

de Bono, E. (1994). de Bono’s Thinking Course. London: MICA Management. Resources.

de Bono, E. (2007). Intelligence is not enough. Dublin: Blackhall Publishing.

Erlin, N. P. (2011). The effectiveness of using the media wall chart (wall chart) in improving the ability to write argumentation papers of class $x$ sma negeri 1 Seyegan Sleman (PhD thesis). Fakultas Bahasa dan Seni: Universitas Negeri Yogyakarta.

Hitchcock, D., \& Verheij, B. (2006). Arguing on the toulmin model new essays in argument analysis and evaluation. The Netherlands: Springer. https://doi.org/10.1007/978-1-4020-4938-5

Hyland, K. (1990). A genre description of the argumentative essay. RELC Journal, 21(1), 66-78. 
https://doi.org/10.1177/003368829002100105

Jamian, A. R. (2011). The problems pertaining to reading and writing skills in Malay language among rural primary school children.. Jurnal Pendidikan Bahasa Melayu, 1(1), 1-12.

John, A. P., \& Fatimah, H. (1992). To develop students' thinking power through KBSM subjects. Jurnal Pendidikan Guru, Bil. 8, 1-15.

Maharam, M. (2000). Writing skills and general studies: Between attitudes and needs. In A. L. Samian, \& M. S. Haron (Eds.), Proceedings of Persidangan Kebangsaan Pengajian Umum di Alaf Baru (pp. 251-262). Bangi: Pusat Pengajian Umum Kebangsaan Universiti Kebangsaan Malaysia.

Maimunah, N., \& Hashimah M. Y. (2017). The role of form six teachers in shaping self-directed students and improving 21st century skills. Jurnal Kurikulum \& Pengajaran Asia Pasifik, 5(1), 1-6.

Maimunah, O. (2004). Kemahiran berfikir siri pengurusan INTAN. Kuala Lumpur: Institut Tadbiran Awam Negara (INTAN).

Maria, S., \& Nurulhuda, A. R. (2013). Approaches and teaching of thinking. In N. A. Rahman, \& Md N. Ibrahim (Eds.), Pemikiran kritis dan kreatif: Konsep, pendekatan dan aplikasi dalam pengajaran dan pembelajaran (pp. 43-69). Tanjung Malim: Penerbit Universiti Sultan Idris.

Marzni, M. M., \& Marni, J. (2021). A viewpoint of the implementation of qualitative case studies on malay language education research naturalisation. Asian Journal of Civilization Studies (AJOCS), 3(2), 93-111.

Mason, J. (2002). Qualitative researching. London: SAGE Publication, Inc.

Maxwell, J. A. (2008). Designing a qualitative study. In L. Bickman, \& D. J. Rog (Eds.), The sage handbook of applied social research methods (pp. 214-253). California: SAGE Publications Inc. https://doi.org/10.4135/9781483348858.n7

Merriam, S. B. (1988). Case study research in education: A qualitative approach. San Francisco: Jossey-Bass Publishers.

Merriam, S. B. (2009). Qualitative research a guide to design and implementation: Revised and expanded from qualitative research case study application in education. San Francisco: Jossey-Bass A Wiley Imprint.

Ministry of Education, Malaysia. (2013). Malaysian education blueprint (2013-2025). Putrajaya: Education Policy Planning and Research Division.

Moore, N. S., \& MacArthur, C. A. (2011). The effects of being a reader and of observing readers on fifth-grade students' argumentative writing and revising. Reading and Writing, 25(6), 1449-1478. https://doi.org/10.1007/s11145-011-9327-6

Noor Rohana, M. (2007). Monograf analisis aras kognitif pembelajaran bahasa dalam kalangan pelajar-pelajar komuniti pulau dan pesisir pantai. Kuala Terengganu: Penerbit Universiti Malaysia Terengganu.

Noriah, M. I., Siti Fatimah, M. Y., Mohd Izham, M. H., \& Siti Rahaya, A. (2010). Case Study. In N. Idris (Ed.), Penyelidikan dalam pendidikan (pp. 345-371). Kuala Lumpur: Mc Graw Hill Education.

Norliza, A. B., Juliana, A., \& Juriah, L. (2010). Metacognitive awareness, critical and creative thinking skills in Malay language teaching. In J. Long (Ed.), Kaedah pengajaran \& pembelajaran bahasa melayu (pp. 103-132). Bangi: Penerbit Universiti Kebangsaan Malaysia.

Nur Hidayah, I. (2015, October). Higher order thinking skills in 21st century education. Pelita Bahasa, 3, 10-13.

Nureeyah, M. (2015). Enhancing students' argumentative writing performance and critical thinking skills through incorporation of concept mapping and content-based instruction ( $\mathrm{PhD}$ thesis). School of Educational Studies: Universiti Sains Malaysia.

Rajendran, N. S. (2000). Teaching higher-order thinking skills in classrooms: Learning from the experiences of Malaysia. In Proceedings of Thinking Qualities Initiatives Conference Hong Kong 2000 (pp. 1-20). Hong Kong Baptist University, Centre for Educational Development.

Rajendran, N. S. (2001a). The teaching of higher- order thinking skills in Malaysia. Journal of Southeast Asian Education, 2(1), 42-65.

Rajendran, N. S. (2001b). The practices of thinking skills in teaching and learning the Malay Language in the classroom. In Proceedings of Konvensyen Pendidikan Ke-10 (pp. 1-20). Kuala Lumpur, Institut Bahasa Melayu Malaysia. 
Rajendran, N. S. (2001c). Teaching higher-level thinking skills: Teachers' readiness to control the teaching and learning process. In Proceedings of Seminar/Pameran Projek KBKK: Poster Warisan-PendidikanWawasan (pp. 1-13). Putrajaya, Pusat Perkembangan Kurikulum.

Rajendran, N. S. (2002). The contributing of Malay language towards higher-order thinking skills development. In Proceedings of Persidangan Antarabangsa Bahasa Melayu Kedua (pp. 1-12). Beijing, China.

Rajendran, N. S. (2008). Teaching and acquiring higher-order thinking skills theory and practice. Tanjong Malim: Penerbit Universiti Pendidikan Sultan Idris.

Rashid, Z. A. (2016). Tahap kesediaan guru dalam aspek pengetahuan dan keperluan latihan berfokuskan aplikasi KBAT (Degree Dissertation). Fakulti Pendidikan Teknikal \& Vokasional: Universiti Tun Hussein Onn Malaysia.

Roselan, B. (2001). Interaksi lisan pengajaran penulisan Bahasa melayu daripada perspektif guru (PhD thesis). Faculty of Education: Universiti Kebangsaan Malaysia.

Rozita, R. S., \& Abdul Rasid, J. (2012). Excellent teachers essay writing classroom instructional practice: a case study from multiple locations. Asia Pacific Journal of Educators and Education, 27, 51-68.

Said, M. S. (2016). Memupuk budaya berfikir aras tinggi melalui kemahiran mengkategori dalam kalangan kanak-kanak pra sekolah. In Proceedings of Seminar Penyelidikan Tindakan Pendidik Guru 20161 Pensyarah 1Penyelidikan (pp. 431-439). Besut: Institut Pendidikan Guru Kampus Sultan Mizan.

Shahlan, S., Shalinawati, R., \& Saemah, R. (2013). The contribution of meta-cognitive elements on essay writing performance. Jurnal Pendidikan Bahasa Melayu, 3(2), 79-91.

Shamsuddin, M., Ruzlan, M. A., \& Siti Noor, I. (2016). Tahap amalan penerapan kemahiran pemikiran kritis (KPK) di sekolah menengah berprestasi tinggi, sederhana dan rendah. International Seminar on Generating Knowledge Through Research (pp. 967-976). Sintok: UUM-UMSIDA.

Sharifah Nor, P., Nor Adibah, G., Mohd Mahzan, T., \& Aliza, A. (2012). Malay language teachers' concern towards implementing critical and creative thinking skills. Jurnal Pendidikan Bahasa Melayu, (2), 19-31.

Siti Khairiah, M. Z. (2012). Upholding the Malay language as the language of wisdom. Pelita Bahasa, 10(8), 21-25.

Siti Zabidah, M. (2006). Kesan pendekatan penyebatian kemahiran berfikir kreatif dalam pengajaran karangan deskriptif dan karangan imaginatif dalam kalangan pelajar tingkatan empat ( $\mathrm{PhD}$ thesis). School of Educational Studies: Universiti Sains Malaysia.

Suhaimi, Z. O., Baharuddin, A., Hasnah, M., Norasykin, M. Z., \& Zaleha, A. (2014). Penerapan Kemahiran Berfikir Aras Tinggi Melalui Model Stesen Rotasi Pelbagai Mod. In Konvensyen Antarabangsa Jiwa Pendidik (pp. 1-16). Johor Bahru: Fakulti Pendidikan, Universiti Teknologi Malaysia.

Sulaiman, M., \& Ahmad Khair, M. N. (2007). Seni Mengarang. Shah Alam: Karisma Publications Sdn. Bhd.

Sulaiman, W. M., \& Norkhairiah, H. (2011). Application of thinking skills in the teaching of islamic religious knowledge. Journal of Applied Research in Education, 15(1\&2), 43-58.

Suria, B., \& Juriah, L. (2010). Pedagogy thinkers in prewriting activities Malay. In L. Juriah (Ed.), Kaedah pengajaran \& pembelajaran Bahasa Melayu (pp. 172-188). Bangi: Penerbit Universiti Kebangsaan Malaysia.

Toulmin, S. E. (1958). The uses of argument. London: Cambridge University Press.

Toulmin, S. E. (2003). The uses of argument updated edition. London: Cambridge University Press. https://doi.org/10.1017/CBO9780511840005

Wan Shahrazad, W. S., \& Rozainee, K. (2006). Ability to think critically among university students. In N. A. Razak, R. Khairudin, \& R. Vengadasamy (Eds.), Isu-isu pendidikan bahasa sastera dan psikologi di Malaysia (pp. 88-98). Bangi: Penerbit Universiti Kebangsaan Malaysia.

Wolfe, C. R., Britt, M. A., \& Butler, J. A. (2009). Argumentation schema and the myside bias in written argumentation. Written Communication, 26, 183-209. https://doi.org/10.1177/0741088309333019

Wood, N. V. (2001). Writing argumentative essays (2nd ed.). New Jersey: Prentice Hall International.

Yahya, O. (2003, November). Implementation of thinking skills in Malay language teaching from the perspective of teachers. Jurnal Bahasa, 3(1), 136-159. 
Yahya, O. (2014). The role of the Malay language teachers in higher-order thinking skills. Dewan Bahasa, 14(5), 20-24.

Zaini, M., Juriah, L., \& Zarin, I. (2013). Pembangunan modal insan berkualiti dalam sistem pendidikan kebangsaan: penguasaan dwibahasa, kemahiran berfikir dan kemahiran ICT. In J. Long, M. K. Jainabee, \& M. Zaini (Eds.), Pemerkasaan Sistem Pendidikan: Pembangunan Modal Insan dan Jati Diri Kebangsaan (pp. 233-258). Bangi: Penerbit Universiti Kebangsaan Malaysia.

Zhu, W. (2001). Performing argumentative writing in English: Difficulties, processes and strategies. TESL Canada Journal, 19(1), 34-50. https://doi.org/10.18806/tesl.v19i1.918

\section{Copyrights}

Copyright for this article is retained by the author(s), with first publication rights granted to the journal.

This is an open-access article distributed under the terms and conditions of the Creative Commons Attribution license (http://creativecommons.org/licenses/by/4.0/). 